Pengaruh Struktur Modal, Ukuran Perusahaan Dan Profitabilitas Terhadap Nilai Perusahaan (Studi Empiris Pada Sektor Pertambangan Yang Terdaftar Di Bursa Efek Indonesia Periode 2013-2017)

\title{
PENGARUH STRUKTUR MODAL, UKURAN PERUSAHAAN DAN PROFITABILITAS TERHADAP NILAI PERUSAHAAN \\ (Studi Empiris pada Sektor Pertambangan yang Terdaftar di Bursa Efek Indonesia periode 2013-2017)
}

\author{
Gita Dewi Ratnasari, Dr. H. Ayus A. Yusuf, SE., M.Si., \\ Program Studi Manajemen Fakultas Ekonomi Universitas Kuningan \\ gitadratnasari@gmail.com
}

\begin{abstract}
ABSTRAK
Tujuan dari penelitian ini adalah untuk menguji dan menganalisis pengaruh Struktur Modal, Ukuran Perusahaan dan Profitabilitas terhadap Nilai Perusahaan baik secara parsial maupun secara simultan pada Sektor Pertambangan yang terdaftar di Bursa Efek Indonesia Periode 2013-2017. Metode penelitian yang digunakan dalam penelitian ini yaitu metode deskriptif dan verifikatif dengan pendekatan kuantitatif. Populasi dalam penelitian ini adalah semua perusahaan pertambangan di Bursa Efek Indonesia Periode 2013-2017. Sampel diambil dengan menggunakan metode purposive sampling, dan diperoleh 15 perusahaan. Teknik analisis data yang digunakan adalah analisis regresi data panel. Hasil penelitian menunjukkan bahwa Struktur Modal, Ukuran Perusahaan dan Profitabilitas secara simultan berpengaruh positif signifikan terhadap Nilai Perusahaan. Dan secara parsial menunjukkan hasil bahwa Struktur Modal, Ukuran Perusahaan dan Profitabilitas masing-masing berpengaruh positif signifikan terhadap Nilai Perusahaan.
\end{abstract}

Kata Kunci: Struktur Modal (DER), Ukuran Perusahaan (Total Aset), Profitabilitas (ROA) dan Nilai Perusahaan (Tobin's Q).

\begin{abstract}
This study aims to test and analyze the effect of Capital Structure, Firm Size and Profitability on Corporate Value both partially and simultaneously of The Mining Sector Companies registered in Indonesian Stock Exchange period 2013-2017. The research method used in this research is descriptive and verificative method with quantitative approach. The population in this research is all mining companies of Indonesian Stock Exchange period 2013-2017. The samples taken by using purposive sampling method and acquired 15 companies. Analysis technique used is panel data regression analysis. The results of this research show that the Capital Structure, Firm Size and Profitability have significant and positive effect on Corporate Value simultaneously. While, the Capital Structure, Firm Size and Profitability have significant and positive effect on Corporate Value partially.
\end{abstract}

Keyword: Capital Structure (DER), Firm Size (Total Asset), Profitability (ROA) and Firm Value (Tobin's Q). 
Pengaruh Struktur Modal, Ukuran Perusahaan Dan Profitabilitas Terhadap Nilai Perusahaan (Studi Empiris Pada Sektor Pertambangan Yang Terdaftar Di Bursa Efek Indonesia Periode 2013-2017)

\section{PENDAHULUAN}

\section{Latar Belakang}

Banyak industri membentuk perekonomian yang kuat di Indonesia, salah satu yang memimpin adalah industri pertambangan. Sektor pertambangan berkontribusi besar terhadap Produk Domestik Bruto Indonesia. Pada tahun 2011, sekitar 11\% Produk Domestik Bruto Indonesia berasal dari industri pertambangan. Indonesia merupakan eksportir batu bara termal terbesar di dunia. Indonesia juga merupakan pemasok tembaga, emas, nikel dan timah (Dirckx, Regional Head, 2011). Tetapi bawah ini ada grafik yang menunjukkan perkembangan harga saham industri pertambangan itu sendiri.

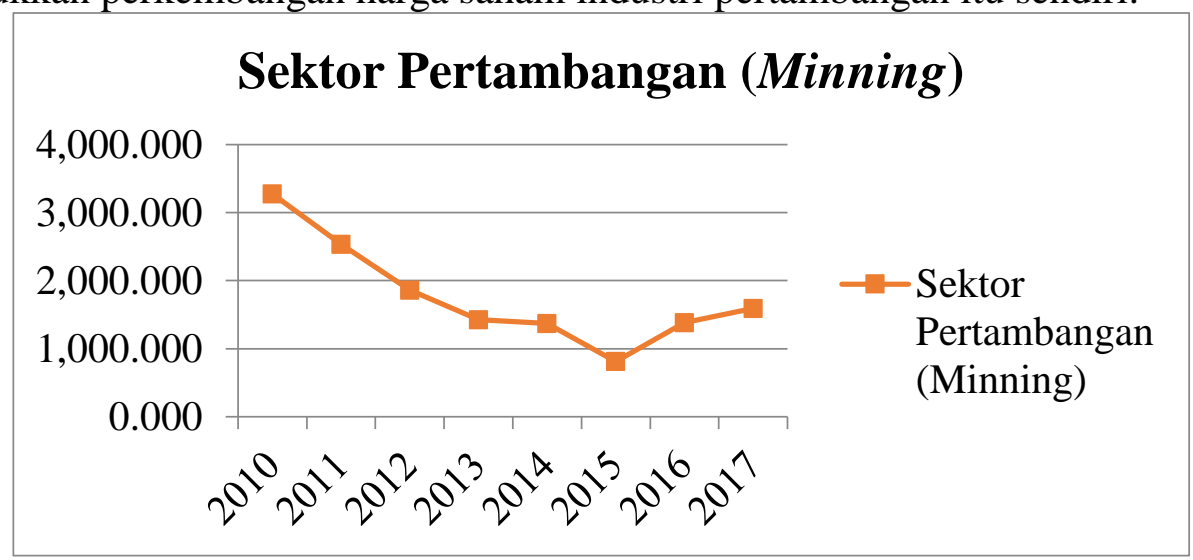

Gambar 1

Grafik Perkembangan Harga Saham Industri Pertambangan (Minning)

Dari gambar 1 terlihat jelas siklus harga saham Sektor Pertambangan mengalami fluktuasi dan cenderung menurun dari tahun 2010-2017. Menurunnya harga saham untuk sektor pertambangan itu sendiri diakibatkan karena Perusahaan Tambang Indonesia sedang mengalami masalah lemahnya harga komoditi dan menurunnya permintaan Tiongkok dan negara berkembang lainnya yang menyebabkan penurunan yang signifikan atas kinerja keuangan perusahaan pertambangan di Indonesia.

Harga saham itu sendiri mencerminkan nilai suatu perusahaan. Kenaikan harga saham menjadi penting bagi setiap perusahaan karena semakin tinggi harga saham sebuah perusahaan, maka semakin tinggi nilai perusahaan tersebut (Martono dan Agus Harjito, 2010). Menurut Harmono (2009:233), Nilai Perusahaan adalah kinerja perusahaan yang dicerminkan oleh harga saham yang dibentuk oleh permintaan dan penawaran pasar modal yang merefleksikan penilaian masyarakat terhadap kinerja perusahaan.

Untuk mengetahui nilai perusahaan melalui indikator rasio Tobin's Q, berikut adalah nilai Tobin's Q Perusahaan Pertambangan yang terdaftar di Bursa Efek Indonesia periode 2013-2017 disajikan dalam tabel 1.

Tabel 1

Data Nilai Perusahaan Pertambangan di BEI periode 2013-2017

\begin{tabular}{|c|c|c|c|c|c|c|c|c|}
\hline \multirow{2}{*}{ No. } & \multirow{2}{*}{$\begin{array}{l}\text { NAMA } \\
\text { EMITEN }\end{array}$} & \multicolumn{5}{|c|}{ Nilai Perusahaan } & \multirow{2}{*}{ Rata-rata } & \multirow{2}{*}{ Keterangan } \\
\hline & & 2013 & 2014 & 2015 & 2016 & 2017 & & \\
\hline 1. & ADRO & 0,58 & 0,57 & 0,44 & 0,71 & 0,72 & $\mathbf{0 , 6 0}$ & Tidal Ideal \\
\hline 2. & ANTM & 0,61 & 0,63 & 0,48 & 0,8 & 0,67 & 0,64 & Tidal Ideal \\
\hline 3. & ARII & 0,72 & 0,57 & 0,57 & 0,63 & 0,80 & 0,66 & Tidal Ideal \\
\hline 4. & BSSR & 1,86 & 1,51 & 1,12 & 1,31 & 1,65 & 1,49 & Ideal \\
\hline 5. & DEWA & 0,31 & 0,30 & 0,31 & 0,32 & 0,33 & $\mathbf{0 , 3 1}$ & Tidal Ideal \\
\hline
\end{tabular}


Pengaruh Struktur Modal, Ukuran Perusahaan Dan Profitabilitas Terhadap Nilai Perusahaan (Studi Empiris Pada Sektor Pertambangan Yang Terdaftar Di Bursa Efek Indonesia Periode 2013-2017)

\begin{tabular}{|c|c|c|c|c|c|c|c|c|}
\hline 6. & ELSA & 0,74 & 0,80 & 0,16 & 0,12 & 0,63 & $\mathbf{0 , 4 9}$ & Tidal Ideal \\
\hline 7. & ENRG & 0,45 & 0,46 & 0,56 & 0,59 & 0,54 & $\mathbf{0 , 5 2}$ & Tidal Ideal \\
\hline 8. & INCO & 0,33 & 0,49 & 0,26 & 0,39 & 0,41 & $\mathbf{0 , 3 8}$ & Tidal Ideal \\
\hline 9. & ITMG & 1,48 & 0,95 & 0,52 & 1,09 & 1,16 & $\mathbf{1 , 0 4}$ & Ideal \\
\hline 10. & MITI & 1,98 & 0,72 & 0,77 & 0,59 & 0,58 & $\mathbf{0 , 9 3}$ & Tidal Ideal \\
\hline 11. & MYOH & 0,74 & 0,67 & 0,65 & 0,74 & 0,84 & $\mathbf{0 , 7 3}$ & Tidal Ideal \\
\hline 12. & PTBA & 1,75 & 1,59 & 0,74 & 1,38 & 4,55 & $\mathbf{2 , 0 0}$ & Ideal \\
\hline 13. & PTRO & 0,48 & 0,46 & 0,40 & 0,44 & 0,54 & $\mathbf{0 , 4 6}$ & Tidal Ideal \\
\hline 14. & TINS & 0,99 & 0,99 & 0,58 & 0,71 & 0,65 & $\mathbf{0 , 7 8}$ & Tidal Ideal \\
\hline 15. & TOBA & 0,58 & 0,63 & 0,54 & 0,77 & 0,86 & $\mathbf{0 , 6 8}$ & Tidal Ideal \\
\hline
\end{tabular}

Sumber: www.idx.co.id (Data diolah)

Dari tabel 1 dapat dilihat bahwa dari 15 Perusahaan Pertambangan di BEI periode 2013-2017, ada 3 perusahaan yang tergolong Perusahaan Pertambangan yang ideal dari segi Nilai Perusahaannya dan sisanya tergolong Perusahaan Pertambangan yang tidak ideal. Karena rata-rata nilai Tobin's Q kurang dari 1. Dan itu menjadi permasalahan bagi perusahaan pertambangan itu sendiri. Karena dengan nilai perusahaan yang tidak ideal dapat membuat investor dan pasar tidak percaya terhadap prospek perusahaan.

Struktur Modal merupakan gambaran dari bentuk proporsi finansial perusahaan yaitu antara modal yang dimiliki yang bersumber dari utang jangka panjang dan modal sendiri yang menjadi sumber pembiayaan suatu perusahaan (Irham Fahmi, 2015). Ukuran perusahaan merupakan ukuran besar kecilnya sebuah perusahaan yang ditunjukan atau dinilai oleh total asset, total penjualan, jumlah laba, beban pajak dan lain-lain (Brigham \& Houston, 2010:4). Profitabilitas adalah kemampuan perusahaan memperoleh laba dalam hubungannya dengan penjualan, total aktiva maupun modal sendiri (R. Agus Sartono, 2010:122).

\section{Rumusan Masalah}

a. Bagaimana gambaran mengenai variabel Nilai Perusahaan, Struktur Modal, Ukuran Perusahaan dan Profitabilitas?

b. Bagaimana pengaruh Struktur Modal, Ukuran Perusahaan dan Profitabilitas terhadap Nilai Perusahaan?

c. Bagaimana pengaruh Struktur Modal terhadap Nilai Perusahaan?

d. Bagaimana pengaruh Ukuran Perusahaan terhadap Nilai Perusahaan?

e. Bagaimana pengaruh Profitabilitas terhadap Nilai Perusahaan?

\section{Tujuan Penelitian}

Berdasarkan rumusan masalah diatas maka tujuan dari penelitian ini untuk menghasilkan fakta empiris berupa model yang dapat menjelaskan tentang:

a. Gambaran mengenai variabel Nilai Perusahaan, Struktur Modal, Ukuran Perusahaan dan Profitabilitas.

b. Pengaruh Struktur Modal, Ukuran Perusahaan dan Profitabilitas terhadap Nilai Perusahaan.

c. Pengaruh Struktur Modal yang diukur dengan debt to equity ratio terhadap Nilai Perusahaan.

d. Pengaruh Ukuran Perusahaan yang diukur dengan total aset terhadap Nilai Perusahaan. 
Pengaruh Struktur Modal, Ukuran Perusahaan Dan Profitabilitas Terhadap Nilai Perusahaan (Studi Empiris Pada Sektor Pertambangan Yang Terdaftar Di Bursa Efek Indonesia Periode 2013-2017)

e. Pengaruh Profitabilitas yang diukur dengan return on asset terhadap Nilai Perusahaan.

\section{LANDASAN TEORI}

\section{Tinjauan Literatur}

\section{Signalling Theory (Teori Sinyal)}

Brigham dan Houston (2012:154) menyatakan bahwa sinyal adalah suatu tindakan yang diambil oleh manajemen perusahaan yang memberikan petunjuk bagi investor tentang bagaimana manajemen memandang prospek perusahaan. Sinyal ini berupa informasi mengenai apa yang sudah dilakukan oleh manajemen untuk merealisasikan keinginan pemilik.

Teori sinyal berguna untuk mengatasi adanya asimetri informasi. Asimetri informasi akan menyebabkan investor cenderung melindungi dirinya dengan memberikan harga yang rendah bagi perusahaan. Akibatnya harga saham perusahaan yang menjadi proksi dari nilai perusahaan menjadi semakin rendah.

\section{Nilai Perusahaan}

Menurut Harmono (2009:233), nilai perusahaan adalah kinerja perusahaan yang dicerminkan oleh harga saham yang dibentuk oleh permintaan dan penawaran pasar modal yang merefleksikan penilaian masyarakat terhadap kinerja perusahaan.

Nilai perusahaan adalah persepsi investor terhadap tingkat keberhasilan perusahaan yang sering dikaitkan dengan harga saham. Harga saham yang tinggi membuat nilai perusahaan juga tinggi, dan meningkatkan kepercayaan pasar tidak hanya terhadap kinerja perusahaan saat ini namun juga pada prospek perusahaan di masa mendatang. Dengan memaksimalkan nilai perusahaan berarti juga memaksimalkan tujuan utama perusahaan. Meningkatnya nilai perusahaan adalah sebuah prestasi yang sesuai dengan keinginan para pemiliknya, karena dengan meningkatnya nilai perusahaan, maka kesejahteraan para pemilik juga akan meningkat.

\section{Struktur Modal}

Struktur Modal merupakan gambaran dari bentuk proporsi finansial perusahaan yaitu antara modal yang dimiliki yang bersumber dari utang jangka panjang (long-term liabilities) dan modal sendiri (shareholder's equity) yang menjadi sumber pembiayaan suatu perusahaan (Irham Fahmi, 2015).

Menurut Teory Trade-Off, penggunaan utang akan meningkatkan nilai perusahaan tapi hanya sampai titik tertentu. Setelah titik tersebut, penggunaan utang justru akan menurunkan nilai perusahaan karena kenaikan keuntungan dari penggunaan utang tidak sebanding dengan kenaikan biaya financial distress dan agency problem. Titik balik tersebut disebut struktur modal yang optimal, menunjukkan jumlah utang perusahaan yang optimal.

\section{Ukuran perusahaan}

Menurut Brigham \& Houston (2010:4) ukuran perusahaan adalah sebagai berikut: "Ukuran perusahaan merupakan ukuran besar kecilnya sebuah perusahaan yang ditunjukan atau dinilai oleh total aset, total penjualan, jumlah laba, beban pajak dan lain-lain”.

Perusahaan dengan ukuran yang lebih besar memiliki akses yang lebih besar untuk mendapat sumber pendanaan dari berbagai sumber, sehingga untuk 
Pengaruh Struktur Modal, Ukuran Perusahaan Dan Profitabilitas Terhadap Nilai Perusahaan (Studi Empiris Pada Sektor Pertambangan Yang Terdaftar Di Bursa Efek Indonesia Periode 2013-2017)

memperoleh pinjaman dari krediturpun akan lebih mudah karena perusahaan dengan ukuran besar memiliki probabilitas lebih besar untuk memenangkan persaingan atau bertahan dalam industri.

\section{Profitabilitas}

Menurut Kasmir (2011:196), yang menyatakan bahwa "Rasio profitabilitas merupakan rasio untuk menilai kemampuan perusahaan dalam mencari keuntungan". Rasio Profitabilitas (Profitability Ratio) adalah rasio atau perbandingan untuk mengetahui kemampuan perusahaan untuk mendapatkan laba (profit) dari pendapatan (earning) terkait penjualan, aset, dan ekuitas berdasarkan dasar pengukuran tertentu.

Indikator pertumbuhan profitabilitas perusahaan sangat penting diperhatikan untuk mengetahui sejauh mana investasi yang akan dilakukan investor di suatu perusahaan mampu memberikan return yang sesuai dengan tingkat yang disyaratkan investor (Tandelilin, 2010:372).

\section{Kerangka Pemikiran}

Gambaran kerangka pemikiran penelitian ini sebagai berikut: Variabel Independen

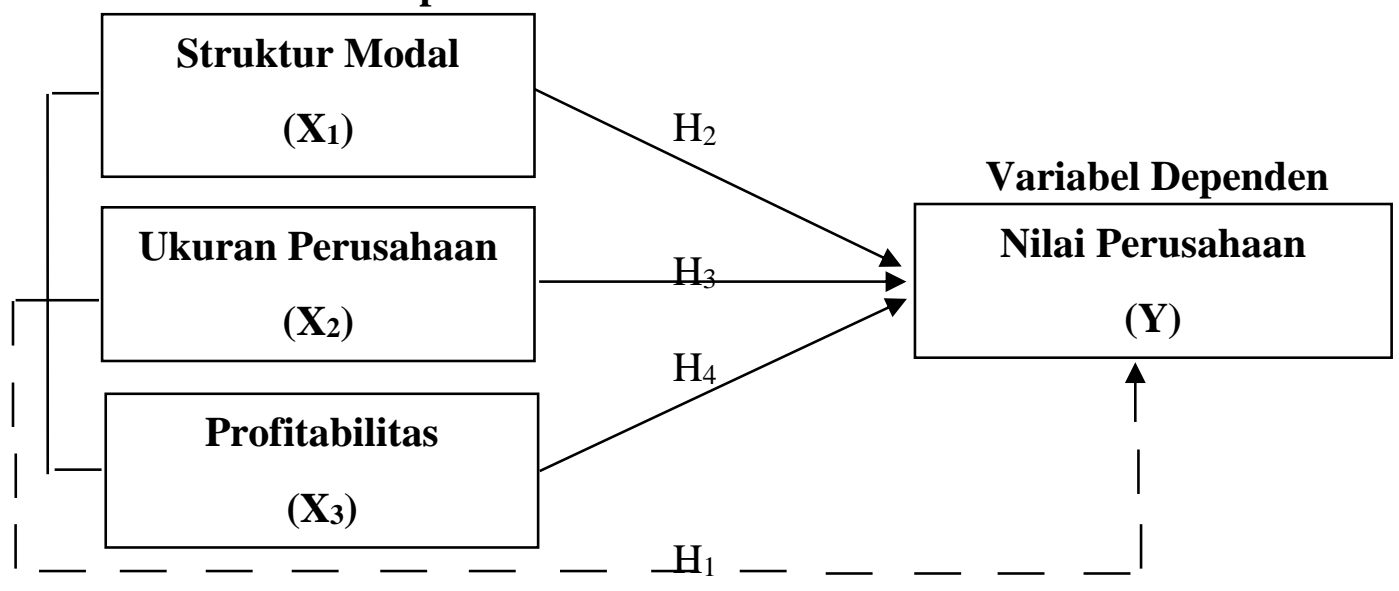

Gambar 2

Paradigma Penelitian

\section{Hipotesis Penelitian}

Berdasarkan kerangka pemikiran diatas, maka hipotesis yang dibangun pada penelitian ini adalah sebagai berikut:

$\mathrm{H}_{1} \quad$ : Struktur Modal, Ukuran Perusahaan dan Profitabilitas berpengaruh secara bersama-sama terhadap Nilai Perusahaan

$\mathrm{H}_{2} \quad$ : Struktur Modal berpengaruh positif terhadap Nilai Perusahaan

$\mathrm{H}_{3}$ : Ukuran Perusahaan berpengaruh positif terhadap Nilai Perusahaan

$\mathrm{H}_{4} \quad$ : Profitabilitas berpengaruh positif terhadap Nilai Perusahaan

\section{METODE PENELITIAN}

Metode yang digunakan penulis dalam penelitian ini adalah metode deskriptif dan verifikatif dengan pendekatan kuantitatif. Menurut Sugiyono (2015:147), Metode deskriptif adalah metode yang digunakan untuk menggambarkan atau menganalisis data dengan cara mendeskripsikan atau menggambarkan data yang telah terkumpul sebagaimana adanya tanpa bermaksud membuat kesimpulan yang berlaku untuk umum 
Pengaruh Struktur Modal, Ukuran Perusahaan Dan Profitabilitas Terhadap Nilai Perusahaan (Studi Empiris Pada Sektor Pertambangan Yang Terdaftar Di Bursa Efek Indonesia Periode 2013-2017)

atau generalisasi. Sedangkan Metode Verifikatif adalah penelitian melalui pembuktian untuk menguji hipotesis hasil penelitian deskriptif dengan suatu perhitungan statistika sehingga di dapat hasil pembuktian yang menunjukkan hipotesis ditolak atau diterima (Sugiyono, 2015:6).

Populasi dalam penelitian ini adalah laporan keuangan tahunan perusahaan Pertambangan yang terdaftar di Bursa Efek Indonesia (BEI) yang terdiri dari 41 perusahaan. Dan teknik sampel yang digunakan adalah teknik purposive sampling.

Dalam penelitian ini, analisis yang digunakan adalah analisis Regresi Data Panel dengan pengujian Asumsi Klasik, Koefisien Determinasi, serta pengujian hipotesis (uji F dan uji t).

\section{HASIL DAN PEMBAHASAN}

Hasil

A. Uji Asumsi Klasik

Tabel 2

Hasil Uji Asumsi Klasik

\begin{tabular}{|l|c|l|}
\hline \multicolumn{1}{|c|}{ Jenis Pengujian } & \multicolumn{1}{|c|}{ Alat Uji } & \multicolumn{1}{|c|}{ Hasil Pengujian } \\
\hline Uji Normalitas & $\begin{array}{c}\text { Kolmogorov } \\
\text { Smirnov Test }\end{array}$ & $\begin{array}{l}\text { Data berdistribusi normal dimana } \\
\text { masing-masing variabel memiliki } \\
\text { nilai kolmogorov smirnov }>0,05 .\end{array}$ \\
\hline Uji Multikolonieritas & $\begin{array}{c}\text { Korelasi antar } \\
\text { variabel }\end{array}$ & $\begin{array}{l}\text { Tidak terjadi korelasi antar variabel } \\
\text { independen karena koefisien } \\
\text { korelasi antar variabel }<0,80 .\end{array}$ \\
\hline Uji Heteroskedastisitas & $\begin{array}{c}\text { Uji White } \\
\text { obs*-aquare })\end{array}$ & $\begin{array}{l}\text { nilai p-value obs } *_{\text {-square sebesar }} \\
0,7694>0,05 \text { maka tidak terjadi } \\
\text { heteroskedastisitas }\end{array}$ \\
\hline Uji Autokolerasi & Breusch-Pagan & $\begin{array}{l}\text { Tidak terjadi autokolerasi karena } \\
\text { nilai breush-pagan sebesar 0,1786 } \\
>0,05\end{array}$ \\
\hline
\end{tabular}

B. Hasil Estimasi Model Regres Data Panel

Hasil estimasi model common effect dapat dilihat pada tabel berikut:

\section{Tabel 3}

Hasil Estimasi Model Common Effect

Dependent Variable: NILAIPERUSAHAAN?

Method: Pooled Least Squares

Date: 06/17/19 Time: 17:38

Sample: 20132017

Included observations: 5

Cross-sections included: 15

Total pool (balanced) observations: 75

\begin{tabular}{ccccc}
\hline \hline Variable & Coefficient & Std. Error & t-Statistic & Prob. \\
\hline \hline C & 0.591622 & 0.029708 & 19.91440 & 0.0000 \\
STRUKTURMODAL? & 0.022566 & 0.003562 & 6.335290 & 0.0000 \\
UKURANPERUSAHAAN? & 0.025829 & 0.003485 & 7.410516 & 0.0000 \\
PROFITABILITAS? & 0.014967 & 0.004299 & 3.481833 & 0.0009
\end{tabular}


Pengaruh Struktur Modal, Ukuran Perusahaan Dan Profitabilitas Terhadap Nilai Perusahaan (Studi Empiris Pada Sektor Pertambangan Yang Terdaftar Di Bursa Efek Indonesia Periode 2013-2017)

\begin{tabular}{lllr}
\hline \hline R-squared & 0.743676 & Mean dependent var & 0.944029 \\
Adjusted R-squared & 0.732846 & S.D. dependent var & 0.278637 \\
S.E. of regression & 0.144019 & Akaike info criterion & -0.985883 \\
Sum squared resid & 1.472648 & Schwarz criterion & -0.862283 \\
Log likelihood & 40.97060 & Hannan-Quinn criter. & -0.936531 \\
F-statistic & 68.66453 & Durbin-Watson stat & 0.614690 \\
Prob(F-statistic) & 0.000000 & & \\
\hline \hline
\end{tabular}

Sumber: Output Eviews versi 10

\section{Interpretasi Model}

$$
\mathrm{Y}=0.591622+0.022566 \mathrm{X}_{1}+0.025829 \mathrm{X}_{2}+0.014967 \mathrm{X}_{3}
$$

Persamaan regresi tersebut mempunyai makna sebagai berikut:

1. Nilai konstanta 0,591622 menunjukkan bahwa ketika semua variabel independen bernilai 0 , maka besarnya nilai variabel dependen sebesar 0,591622 .

2. Nilai koefisien regresi Struktur Modal sebesar 0,022566 menunjukkan ada pengaruh positif terhadap Nilai Perusahaan. Apabila Struktur Modal mengalami kenaikan sebesar 1\% sedangkan variabel lain dianggap konstan, maka Nilai Perusahaan mengalami kenaikan sebesar 0,022566.

3. Nilai koefisien regresi Ukuran Perusahaan sebesar 0,025829 menunjukkan ada pengaruh positif terhadap Nilai Perusahaan. Apabila Ukuran Perusahaan mengalami kenaikan sebesar $1 \%$ sedangkan variabel lain dianggap konstan, maka Nilai Perusahaan mengalami kenaikan sebesar 0,025829.

4. Nilai koefisien regresi Profitabilitas sebesar 0,014967 menunjukkan ada pengaruh positif terhadap Nilai Perusahaan. Apabila Profitabilitas mengalami kenaikan sebesar 1\% sedangkan variabel lain dianggap konstan, maka Nilai Perusahaan mengalami kenaikan sebesar 0,014967.

\section{Koefisien Determinasi}

\section{Tabel 4}

Hasil Uji Koefisien Determinasi

\begin{tabular}{lllr}
\hline \hline R-squared & 0.743676 & Mean dependent var & 0.944029 \\
Adjusted R-squared & 0.732846 & S.D. dependent var & 0.278637 \\
S.E. of regression & 0.144019 & Akaike info criterion & -0.985883 \\
Sum squared resid & 1.472648 & Schwarz criterion & -0.862283 \\
Log likelihood & 40.97060 & Hannan-Quinn criter. & -0.936531 \\
F-statistic & 68.66453 & Durbin-Watson stat & 0.614690 \\
Prob(F-statistic) & 0.000000 & & \\
\hline \hline
\end{tabular}

Sumber: Output Eviews versi 10

Berdasarkan perhitungan tabel di atas nilai Koefisien Determinasi $\left(\mathrm{R}^{2}\right)$ sebesar 0,743676. Hal ini menunjukkan bahwa 74,3676\% perubahan Nilai Perusahaan dapat dijelaskan oleh struktur modal, ukuran perusahaan dan profitabilitas. Sedangkan sisanya sebesar $25,6324 \%$ dipengaruhi oleh variabelvariabel lain. 
Pengaruh Struktur Modal, Ukuran Perusahaan Dan Profitabilitas Terhadap Nilai Perusahaan (Studi Empiris Pada Sektor Pertambangan Yang Terdaftar Di Bursa Efek Indonesia Periode 2013-2017)

E. Uji Hipotesis

1. Uji Simultan

Tabel 5

Hasil Uji Simultan (Uji F)

\begin{tabular}{lllr}
\hline \hline R-squared & 0.743676 & Mean dependent var & 0.944029 \\
Adjusted R-squared & 0.732846 & S.D. dependent var & 0.278637 \\
S.E. of regression & 0.144019 & Akaike info criterion & -0.985883 \\
Sum squared resid & 1.472648 & Schwarz criterion & -0.862283 \\
Log likelihood & 40.97060 & Hannan-Quinn criter. & -0.936531 \\
F-statistic & 68.66453 & Durbin-Watson stat & 0.614690 \\
Prob(F-statistic) & 0.000000 & & \\
\hline \hline
\end{tabular}

Sumber: Output Eviews versi 10

Berdasarkan hasil uji $\mathrm{F}$ pada tabel di atas terlihat bahwa nilai $\mathrm{F}_{\text {hitung }}$ diperoleh sebesar 68,66453. Karena $F_{\text {hitung }}>F_{\text {tabel }}(68,66453>2,73)$, maka $\mathrm{H}_{0}$ ditolak dan $\mathrm{H}_{\mathrm{a}}$ diterima, artinya Struktur Modal, Ukuran Perusahaan dan Profitabilitas secara simultan berpengaruh signifikan terhadap Nilai Perusahaan.

\section{Uji Parsial}

\section{Tabel 6}

Hasil Uji Parsial (Uji t)

\begin{tabular}{ccccc}
\hline \hline Variable & Coefficient & Std. Error & t-Statistic & Prob. \\
\hline \hline C & 0.591622 & 0.029708 & 19.91440 & 0.0000 \\
STRUKTURMODAL? & 0.022566 & 0.003562 & 6.335290 & 0.0000 \\
UKURANPERUSAHAAN? & 0.025829 & 0.003485 & 7.410516 & 0.0000 \\
PROFITABILITAS? & 0.014967 & 0.004299 & 3.481833 & 0.0009 \\
\hline \hline
\end{tabular}

Sumber: Output Eviews versi 10

Berdasarkan hasil Uji t pada tabel di atas, maka dapat dijelaskan sebagai berikut:

a. Berdasarkan hasil pengujian uji parsial (Uji t) menunjukkan bahwa nilai statistik $\mathrm{t}$ ( $\mathrm{t}_{\text {hitung }}$ ) variabel Struktur Modal sebesar 6.335290. Karena nilai $t_{\text {hitung }}>t_{\text {tabel }}(6.335290>1.66660)$ dan taraf signifikan sebesar $0,0000<0,05$, maka $\mathrm{H}_{0}$ ditolak dan $\mathrm{H}_{\mathrm{a}}$ diterima, artinya Struktur Modal secara parsial berpengaruh positif dan signifikan terhadap Nilai Perusahaan.

b. Berdasarkan hasil pengujian uji parsial (Uji t) menunjukkan bahwa nilai statistik $t$ ( $t_{\text {hitung }}$ ) variabel Ukuran Perusahaan sebesar 7.410516. Karena nilai $t_{\text {hitung }}>\mathrm{t}_{\text {tabel }}(7.410516>1.66660)$ dan taraf signifikan sebesar $0,0000<0,05$, maka $\mathrm{H}_{0}$ ditolak dan $\mathrm{H}_{\mathrm{a}}$ diterima, artinya Ukuran Perusahaan secara parsial berpengaruh positif dan signifikan terhadap Nilai Perusahaan.

c. Berdasarkan hasil pengujian uji parsial (Uji t) menunjukkan bahwa nilai statistik $\mathrm{t}\left(\mathrm{t}_{\text {hitung }}\right.$ ) variabel Profitabilitas sebesar 3.481833. Karena nilai $t_{\text {hitung }}>\mathrm{t}_{\text {tabel }}(3.481833>1.66660)$ dan taraf signifikan sebesar $0,0009<0,05$, maka $\mathrm{H}_{0}$ ditolak dan $\mathrm{H}_{\mathrm{a}}$ diterima, artinya Profitabilitas 
Pengaruh Struktur Modal, Ukuran Perusahaan Dan Profitabilitas Terhadap Nilai Perusahaan (Studi Empiris Pada Sektor Pertambangan Yang Terdaftar Di Bursa Efek Indonesia Periode 2013-2017)

secara parsial berpengaruh positif dan signifikan terhadap Nilai Perusahaan.

\section{Pembahasan}

1. Pengaruh Struktur Modal, Ukuran Perusahaan dan Profitabilitas terhadap Nilai Perusahaan

Berdasarkan hasil analisis menunjukkan bahwa struktur modal, ukuran perusahaan dan profitabilitas berpengaruh signifikan terhadap nilai perusahaan pada perusahaan pertambangan yang terdaftar di Bursa Efek Indonesia. Dengan hasil yang signifikan, hasil penelitian ini dapat digeneralisasikan pada anggota populasi. Secara simultan struktur modal, ukuran perusahaan dan profitabilitas dapat digunakan untuk meningkatkan nilai perusahaan. Sehingga dapat dijadikan sebagai salah satu pedoman bagi stakeholder untuk menilai suatu perusahaan baik atau tidaknya dan dapat membantu dalam pengambilan keputusan untuk berinvestasi dan meminjamkan pinjaman modal di perusahaan terpilih.

Hasil uji koefisien determinasi menunjukkan bahwa struktur modal, ukuran perusahaan dan profitabilitas memiliki pengaruh sebesar 74,3676\%, sedangkan sisanya 25,6324\% dipengaruhi oleh variabel lain. Hal ini sesuai dengan penelitian yang dilakukan oleh Rahmantio, Saifi \& Nurlaily (2018) yang menyatakan bahwa DER, ROE, ROA dan Ukuran Perusahaan secara simultan berpengaruh signifikan terhadap Nilai Perusahaan.

\section{Pengaruh Struktur Modal terhadap Nilai Perusahaan}

Berdasarkan hasil dari analisis penelitian ini diketahui bahwa Struktur Modal secara parsial berpengaruh positif dan signifikan terhadap Nilai Perusahaan Sektor Pertambangan yang terdaftar di Bursa Efek Indonesia. Hal ini dapat diartikan bahwa ketika struktur modal naik, maka nilai perusahaan akan mengalami kenaikan dan begitu juga sebaliknya saat struktur modal suatu perusahaan mengalami penurunan maka nilai perusahaannya juga akan turun.

Adanya pengaruh struktur modal terhadap nilai perusahaan disebabkan karena perusahaan yang menggunakan utang sebagai pendanaan perusahaannya dapat memperoleh keuntungan dari pajak. Trade-Off Theory menjelaskan bahwa penggunaan utang akan meningkatkan nilai perusahaan tapi hanya sampai titik optimalnya saja. Perusahaan yang mampu memproposisikan penggunaan utang dengan modal yang dimilikinya bisa memberikan keuntungan pada perusahaan itu sendiri. Dengan adanya utang dapat meningkatkan laba dan proporsi dividen pemegang saham perusahaan, yang akan berpengaruh pada kesejahteraan pemegang saham. Pada saat kesejahteraan pemegang saham terpacai akan menjadi sinyal yang baik bagi perusahaan itu sendiri, yang akan menarik investor baru maupun investor lama untuk menanamkan modal ataupun sahamnya pada perusahaan. Dan secara langsung akan meningkatkan nilai perusahaan itu sendiri.

Adanya pengaruh positif dan signifkan antara struktur modal terhadap nilai perusahaan, sesuai dengan hipotesis yang telah dibangun dimana struktur modal berpengaruh positif terhadap nilai perusahaan dan diperkuat dengan penelitian yang dilakukan oleh Pratama \& Wirawati (2016), Febriana (2016) dan Cecilia Audrey (2018) yang menyatakan bahwa struktur modal berpengaruh positif signifikan terhadap nilai perusahaan. 
Pengaruh Struktur Modal, Ukuran Perusahaan Dan Profitabilitas Terhadap Nilai Perusahaan (Studi Empiris Pada Sektor Pertambangan Yang Terdaftar Di Bursa Efek Indonesia Periode 2013-2017)

\section{Pengaruh Ukuran Perusahaan terhadap Nilai Perusahaan}

Berdasarkan hasil dari analisis penelitian ini diketahui bahwa Ukuran Perusahaan secara parsial berpengaruh positif dan signifikan terhadap Nilai Perusahaan Sektor Pertambangan yang terdaftar di Bursa Efek Indonesia. Dengan kata lain, semakin besar ukuran suatu perusahaan yang dicerminkan oleh total aset akan membuat semakin percaya investor terhadap kemampuan perusahaan tersebut dalam mengembalikan tingkat investasinya. Dalam hal ini ukuran perusahaan dijadikan tolak ukur bahwa perusahaan tersebut mempunyai kinerja yang bagus.

Adanya pengaruh positif disebabkan karena semakin besar suatu perusahaan akan semakin menarik perhatian investor untuk memiliki saham perusahaan. Peningkatan permintaan saham perusahaan akan dapat memacu terhadap naiknya harga saham di pasar modal. Peningkatan harga saham dan ketertarikan yang lebih dari para investor menunjukkan bahwa perusahaan dianggap memiliki "nilai" yang lebih besar dibanding dengan ukuran perusahaan yang kecil. Karena ukuran perusahaan yang besar inilah perusahaan dapat memanfaatkan aktiva yang dimiliki untuk kelangsungan operasi perusahaan ini merupakan sinyal positif perusahaan terhadap investor.

Hal ini sesuai dengan hipotesis yang telah dibangun yaitu adanya pengaruh positif antara ukuran perusahaan terhadap nilai perusahaan. Dan hasil penelitian tersebut sesuai dengan penelitian yang dilakukan oleh Gharaibeh dan Sarea (2015) yang menyatakan ukuran perusahaan berpengaruh positif signifikan terhadap nilai perusahaan dalam judul "The Impact of Capital Structure and Certain Firm Specific Variables on The Value of The Firm: Empirical Evidence from Kuwait". Sesuai pula dengan penelitian yang dilakukan oleh Rudangga \& Sudiarta (2016), serta Febriana (2016) yang menyatakan ukuran perusahaan berpengaruh positif signifikan terhadap nilai perusahaan.

\section{Pengaruh Profitabilitas terhadap Nilai Perusahaan}

Berdasarkan hasil dari analisis penelitian ini diketahui bahwa Profitabilitas secara parsial berpengaruh positif dan signifikan terhadap Nilai Perusahaan Sektor Pertambangan yang terdaftar di Bursa Efek Indonesia. Hal ini menunjukkan bahwa semakin tinggi profitabilitas suatu perusahaan, maka semakin meningkat nilai perusahaannya dan begitu juga sebaliknya, semakin rendah profitabilitas maka semakin menurun nilai perusahaannya.

Adanya pengaruh positif disebabkan karena perusahaan yang mampu menghasilkan keuntungan yang lebih besar akan menarik investor untuk menanamkan modalnya pada perusahaan. Indikator pertumbuhan profitabilitas perusahaan sangat penting diperhatikan untuk mengetahui sejauh mana investasi yang akan dilakukan investor di suatu perusahaan mampu memberikan return yang sesuai dengan tingkat yang diisyaratkan investor (Tandelilin, 2010:372). Dengan banyaknya investor yang percaya terhadap kinerja perusahaan akan membuat banyak investor ingin memiliki saham perusahaan. Hal itu akan membuat harga saham perusahaan meningkat di pasar modal, dan secara langsung akan mampu meningkatkan nilai perusahaan.

Hal tersebut sesuai dengan hipotesis yang dibangun yaitu adanya pengaruh positif antara profitabilitas terhadap nilai perusahaan. Dan hasil penelitian tersebut sesuai dengan penelitian yang dilakukan oleh Nhan \& Quy (2016), Widyantari \& 
Pengaruh Struktur Modal, Ukuran Perusahaan Dan Profitabilitas Terhadap Nilai Perusahaan (Studi Empiris Pada Sektor Pertambangan Yang Terdaftar Di Bursa Efek Indonesia Periode 2013-2017)

Yadnya (2017), serta Sianipar (2017) yang menyatakan bahwa profitabilitas berpengaruh terhadap nilai perusahaan.

\section{KESIMPULAN DAN SARAN}

\section{Kesimpulan}

1. Gambaran mengenai Nilai Perusahaan, Ukuran Perusahaan dan Profitabilitas terhadap Nilai Perusahaan pada Perusahaan Pertambangan periode 2013-2017 adalah sebagai berikut:

- Rata-rata nilai Tobin's Q perusahaan pertambangan adalah sebesar 0,78 artinya nilai perusahaan tidak ideal.

- Rata-rata nilai DER perusahaan pertambangan adalah 53,49\% artinya struktur modal perusahaan dalam keadaan baik.

- Rata-rata aset perusahaan pertambangan adalah sebesar 885 milyar rupiah artinya perusahaan dikategorikan pada Usaha Besar.

- Rata-rata nilai ROA perusahaan pertambangan adalah 3,81\% artinya profitabilitas perusahaan dalam keadaan baik.

2. Struktur Modal, Ukuran Perusahaan dan Profitabilitas berpengaruh positif signifikan terhadap Nilai Perusahaan pada Perusahaan Pertambangan yang terdaftar di BEI periode 2013-2017.

3. Struktur Modal berpengaruh positif signifikan terhadap Nilai Perusahaan pada Perusahaan Pertambangan yang terdaftar di BEI periode 2013-2017.

4. Ukuran Perusahaan berpengaruh positif signifikan terhadap Nilai Perusahaan. pada Perusahaan Pertambangan yang terdaftar di BEI periode 2013-2017

5. Profitabilitas berpengaruh positif signifikan terhadap Nilai Perusahaan pada Perusahaan Pertambangan yang terdaftar di BEI periode 2013-2017.

\section{Saran}

a. Melihat dari rata-rata Nilai Perusahaan yang masih banyak berada di bawah standar $(<1)$, maka seharusnya manajemen harus mampu meningkatkan kembali harga saham dari sektor pertambangannya itu sendiri dengan terus meningkatkan kinerja manajemen dan juga banyak menjalin kerjasama dengan pihak lain baik di dalam maupun luar negeri.

b. Bagi investor yang ingin menginvestasikan dananya ke beberapa perusahaan khususnya perusahaan pertambangan, maka hendaknya memperhatikan faktorfaktor yang mempengaruhi nilai perusahaan diantaranya struktur modal, ukuran perusahaan dan profitabilitas.

c. Berdasarkan hasil penelitian besarnya koefisien determinasi adalah sebesar $74,3676 \%$, maka bagi peneliti selanjutnya diharapkan dapat meneliti faktor-faktor lain yang dapat mempengaruhi nilai perusahaan karena 25,6324\% nilai perusahaan dipengaruhi oleh faktor-faktor lain seperti Kebijakan Dividen, Pertumbuhan Laba, Likuiditas dan Tingkat Inflasi.

\section{DAFTAR PUSTAKA}

Agus H. dan Martono. 2010. Manajemen Keuangan, Edisi Ketiga. Yogyakarta: Ekonosia. Cecilia A. T, Ngatno. (2018). Pengaruh Struktur Modal terhadap Nilai Perusahaan dengan Ukuran Perusahaan dan Umur Perusahaan sebagai Variabel Moderator (Studi Kasus Tahun 2014-2016) pada Perusahaan Sub-Sektor Makanan dan 
Pengaruh Struktur Modal, Ukuran Perusahaan Dan Profitabilitas Terhadap Nilai Perusahaan (Studi Empiris Pada Sektor Pertambangan Yang Terdaftar Di Bursa Efek Indonesia Periode 2013-2017)

Minuman yang terdaftar di BEI. Diponegoro Journal of Social and Politic, Hal 1-16. Brigham dan Houston. 2010. Dasar-dasar Manajemen Keuangan, Edisi III. Jakarta: Salemba Empat.

Brigham dan Houston. 2012. Dasar-dasar Manajemen Keuangan, Buku 1, Edisi 11. Jakarta: Salemba Empat.

Fahmi, I. 2011. Analisis Laporan Keuangan, Cetakan Ke-2. Bandung: Alfabeta.

Febriana, E. (2016). Kepemilikan Saham Manajerial dan Profitabilitas Terhadap Nilai Perusahaan ( Studi pada Perusahaan Manufaktur yang Terdaftar di BEI Pada 2011 2013). Jurnal Ekonomi Bisnis, (Nomor 2), 164-178.

Gharaibeh, A. M. O., \& Sarea, A. M. (2015). The Impact of Capital Structure and Certain Firm Specific Variables on The Value of The Firm: Empirical Evidence from Kuwait. International Journal, Volume 13(Issue 1), 1191-1200.

Gujarati dan Porter. 2012. Dasar-dasar Ekonometrika, Buku 2. Edisi 5. Jakarta: Salemba Empat.

Hanafi, M. M. 2008. Manajemen Keuangan, Edisi 1. Yogyakarta: BPFE.

Harahap. 2007. Analisis Kritis Atas Laporan Keuangan, Edisi Pertama. Jakarta: Raja Grafindo Persada.

Harmono. 2009. Manajemen Keuangan: Berbasis Balanced Scorecard (Pendekatan Teori, Kasus dan Riset Bisnis). Jakarta: Bumi Aksara.

Hartono, J. 2011. Metodologi Penelitian Bisnis: Salah Kaprah dan Pengalamanpengalaman. Yogyakarta: BPFE.

Hoque, J., Hossain, A., \& Hossain, K. (2014). Impact of Capital Structure Policy on Value of The Firm - A Study on Some Selected Corporate Manufacturing Firms Under Dhaka. International Journal, Volume 3(Issue 2), 77-84.

https://ekonomi.kompas.com/read/2011/06/14/18330228/Industri.Pertambangan.Kian.Pr ospektif

https://www.kompasiana.com/heriyanto_rantelino/552a462ef17e614670d6246d/mengin tip-prospek-industri-pertambangan-indonesia

Husnan, S. dan Enny P. 2012. Dasar-dasar Manajemen Keuangan, Edisi Keenam. Yogyakarta: UPP STIM YKPN.

Iman, H. H. (2018). Pengaruh Struktur Modal dan Kepemilikan Institusional terhadap Nilai Perusahaan. Skripsi Akuntansi, Universitas Kuningan.

Kasmir. 2011. Analisis Laporan Keuangan. Jakarta: PT Raja Grafindo Persada.

Kausar, A., Nazir, M. S., \& Butt, H. A. (2014). Capital Structure and Firm Value: Empirical Evidence from Pakistan. Asian Journal of Research in Economics and Finance, Volume 1(Issue 1), 11-22.

Nhan, D. T., \& Quy, V. T. (2016). The Impact of Director Board 's Characteristics on Firm Value: A Study on HOSE. International Journal of Science and Research (IJSR), Volume 5(Issue 2), 646-650.

Pratama, I. G. G. W., \& Wirawati, N. G. P. (2016). Pengaruh Struktur Modal Dan Profitabilitas Terhadap Nilai Perusahaan Dengan Kepemilikan Manajerial Sebagai Pemoderasi. E-Jurnal Akuntansi Universitas Udayana, Vol. 15(No. 3), 1796-1825.

Rahmantio, I., Saifi, M., \& Nurlaily, F. (2018). Pengaruh Debt to Equity Ratio, Return on Equity, Return on Asset dan Ukuran Perusahaan Terhadap Nilai Perusahaan (Studi pada Perusahaan Pertambangan yang Terdaftar di Bursa Efek Indonesia Tahun 2012-2016). Jurnal Administrasi Bisnis (JAB), Volume 57(No. 1), 151-159.

Riyanto, B. 2011. Dasar-dasar Pembelajaran Perusahaan. Yogyakarta: BPFE. 
Pengaruh Struktur Modal, Ukuran Perusahaan Dan Profitabilitas Terhadap Nilai Perusahaan (Studi Empiris Pada Sektor Pertambangan Yang Terdaftar Di Bursa Efek Indonesia Periode 2013-2017)

Rudangga, I. G. N. G., \& Sudiarta, G. M. (2016). Pengaruh Ukuran Perusahaan, Leverage, dan Profitabilitas terhadap Nilai Perusahaan. E-Jurnal Manajemen Unud, Vol. 5(No. 7), 4394-4422.

Sartono, A. 2010. Manajemen Keuangan Teori dan Aplikasi, Edisi 4. Yogyakarta: BPFE. Sianipar, S. (2017). Pengaruh Struktur Modal dan Profitabilitas terhadap Nilai Perusahaan. Jurnal Nasional, Volume 4(No. 1), 1-14.

Sugiyono. 2015. Statistika untuk Penelitian. Bandung: Alfabeta.

Tandelilin. 2010. Portofolio dan Investasi Teori dan Aplikasinya, Edisi Pertama. Yogyakarta: Kanisius.

Weston, J.F dan Copeland. 2008. Dasar-dasar Manajemen Keuangan Jilid II. Jakarta: Erlangga.

Widaryanti. (2009). Analisis Perataan Laba dan Faktor-faktor yang Mempengaruhi pada Perusahaan Manufaktur di Bursa Efek Indonesia. Fokus Ekonomi, Volume 4(No. 2), 60-77.

www.idx.co.id (Laporan Tahunan Perusahaan Pertambangan Periode 2013-2017) 